UDC 614.72: 616

DOI: 10.21668/health.risk/2017.2.06.eng

\title{
ASSESSMENT OF CARCINOGENIC HEALTH RISK FOR POPULATION LIVING IN MONOCITIES AND RURAL SETTELEMENTS
}

\author{
V.M. Boev, D.A. Kryazhev, L.M. Tulina, A.A. Neplokhov \\ Orenburg State Medical University, 6 Sovetskaya Str., Orenburg, 460000, Russian Federation
}

Our research goal was to perform assessment of carcinogenic health risk for population living in monocities and rural settlements in Orenburg region including both total and individual carcinogenic risk assessment. We assessed carcinogenic health risks for population living in cities with industrial enterprises as economic bases (Novotroitsk and Mednogorsk) and rural settlements (Oktyabrskiy, Ilekskiy, and Tyul'ganskiy districts) in Orenburg region. Exposure assessment was based on the data obtained via laboratory research of environmental objects over 2005-2013 (1,265 atmospheric air samples and 1,897 drinking water samples). We determined total carcinogenic risks for population on each territory under multi-environment impacts exerted by chemicals; a share of each chemical in risk formation was also identified. The results we obtained allow us to make a conclusion that monocities' areas are unfavorable in terms of carcinogenic effects on population health. We detected priority carcinogens for each territory in order to work out practical recommendations on lowering carcinogenic risks and on possibility of delayed effects evolvement. Carcinogenic risk caused by chemicals contained in drinking water both in monocities and rural settlements was considered to be acceptable; however, it was 1.5-2 times higher for monocities population. Overall, chromium took the leading role among carcinogens in monocities air; benzene and arsenic occupied the same place in rural settlements air. Chromium, benzpyrene, and arsenic were priority carcinogens contained in drinking water in rural settlements. Our research proves the necessity to work our practical recommendations on lowering carcinogenic risks and on possibility of delayed effects evolvement on regional level.

Key words: total carcinogenic risk, individual carcinogenic risk, multi-environment impact, chemicals, environmental factors.

In contemporary context, public health depends greatly upon actual assurance of rights to a safe living environment and prevention of diseases. According to the World Health Organization (WHO), the highest contribution to population health is made by a group of factors consolidated by the concept of "external environment", which includes numerous elements that pollute air, water, soil, food [7-9, 15].

In recent decades, high prevalence of malignant neoplasms is a challenging issue for the population of Orenburg region, especially for the population in monocities $[1,2,11]$.
Studying the effects of environmental factors on population health is one of the central focuses among other challenges in environmental hygiene. Medical significance of this issue is determined by the need for timely prevention of negative changes in health status associated with the action of environmental factors, their timely correction, which is the basis for primary prevention of diseases [12].

According to $\mathrm{WHO}$, air pollution is the most important specific environmental health risk factor in the European Region [14, 15]. Particular attention should be paid to assessment and prevention of the delayed effects of

(C) Boev V.M., Kryazhev D.A., Tulina L.M., Neplokhov A.A., 2017

Viktor M. Boev - Doctor of Medical Sciences, Professor, Head of Common and Communal Hygiene Department (e-mail: kafedragigiena@ mail.ru; tel.: +7 (3532) 77-71-26).

Dmitriy A. Kryazhev - Candidate of Medical Sciences, senior teacher at Common and Communal Hygiene Department (e-mail: mitya_k87@ mail.ru; tel.: +7 (3532) 77-71-26).

Larisa M. Tulina - Candidate of Medical Sciences, Associate Professor at Common and Communal Hygiene Department (e-mail: k_com.gig@orgma.ru; tel.: +7 (3532) 77-71-26).

Andrey A. Neplokhov - Candidate of Medical Sciences, Associate Professor at Common and Communal Hygiene Department (e-mail: k_com.gig@orgma.ru; tel.: +7 (3532) 77-71-26). 
pollutants on public health data [8]. When assessing risks their complex and combined routes of exposure must be taken into account.

In prevention of delayed effects, assessment of carcinogenic health risk is still very important, which in turn allows early identification of risk factors and working out a package of measures for their elimination. At the same time, a differentiated approach should be considered, with priority risk factors identified for each territory $[3,4,13]$.

Risk assessment activities open up new opportunities to analyze multi-environment impacts and integrated chemicals intake with maximum consideration to the multiple sources, routes and ways of influence, different spectra of emerging effects.

Among the industrial cities of the region, the largest total carcinogenic risk from exposure to atmospheric air pollution was registered in Novotroitsk, then in Orsk, Mednogorsk and Orenburg. The highest share to carcinogenic effects risk in Mednogorsk, Novotroitsk and Orsk is made by the content of chromium oxide $(+6)$ in atmospheric air (share in the total risk of 87,82 and $69 \%$ respectively). In Orenburg, the largest share (57\%) is made by benzene content in the atmospheric air [5]. Sanitary and hygienic rating for the Orenburg region territory in terms of total carcinogenic risk for 2015 showed the highest risk levels exceeding the acceptable ones (1.0E-10-4 - 1.0E-10-6) on 27 territories of the region: in Abdulino, Ponomarevo, Saraktash, Tyul'ganskiy, Oktyabrskiy, Ilekskiy, Matveyevskiy, Aleksandrovskiy, Perevolotskiy, Kuvandykskiy, Belyaevskiy, Tashlinskiy, Sorochinskiy, Krasnogvardeyskiy, Gay, Novoorsk, Novosergievskiy, Sakmara, Adamovskiy, Kvarkenskiy, Yasnenskiy districts, Orenburg city, as well as in Svetlinskoye, Sharlykskiy, Grachevskiy, Orenburgskiy, Pervomaiskiy areas [5]. It should be noted that in the large industrial cities (Orenburg, Orsk), there is a tendency to reducing risk, while in monocities (Mednogorsk, Novotroitsk), there is an increase in carcinogenic and noncarcinogenic risks to the population health.

The earlier comparative reviews on risk assessment in monocities and rural settlements of Orenburg region argue for the urgency of the problem.

Given the wide prevalence of carcinogens in environmental objects, an assessment of their complex impact is of particular interest.

Materials and methods. In order to identify the degree of exposure to pollutants contained in atmospheric air and drinking water, being carcinogenic to humans according to the classification of the International Agency for Research on Cancer (IARC), we assessed carcinogenic health risks for population living in cities with industrial enterprises as economic bases (Novotroitsk, Mednogorsk), and rural settlements (Oktyabrskiy, Ilekskiy and Tyul'ganskiy districts). The assessment of carcinogenic risks to public health was carried out in compliance with the "Guidelines for assessment of public health risk from exposure to chemicals that pollute habitat" $[4,6,10]$. We studied the laboratory reports on environmental objects for the last 5 years. A total of 1,245 samples of atmospheric air and 1,897 samples of drinking water were analyzed.

We studied data of the Regional Information Fund for Socio-Hygienic Monitoring at the FBHI "Center for Hygiene and Epidemiology in Orenburg region", official statistical data forms of territorial body of the Federal State Statistics Service for Orenburg region, and data of the FGA "Orenburg Center for Hydrometeorology and Environmental Monitoring" for 2005-2013. Among the atmospheric air components studied at the fixed stations of "Orenburg Center for Hydrometeorology and Environmental Monitoring" (branch of FSBI "Hydrometeorology and Environmental Monitoring for Volga Region"), 8 pollutants (formaldehyde, benzo (a) pyrene, benzene, ethylbenzene, lead, chromium oxide (+6), nickel and cadmium) have carcinogenic properties; 15 carcinogens (benzo (a) pyrene, benzene, arsenic, nickel, lead, chrome, 2,4-D, chloroform, carbon tetrachloride, 1,2dichloroethane, tetrachlorethylene, bromide dichloromethane, dibromochloromethane, bromoform, and trichlorethylene) were detected in drinking water. When assessing exposure, we used incidence factors of substances' 
concentrations in various media. In the atmospheric air (29,440 samples) and the drinking water from the centralized water supply systems (6,521 samples), we assessed mean concentrations of substances subject to a longterm dynamic surveillance within the framework of socio-hygienic monitoring.

Results and discussion. When identifying hazard, it was found that the major origins of environmental pollution in Novotroitsk were the large enterprises of metallurgical industry, construction and food industries (LLC "Novotroitsk Construction Materials Plant "Argo", JSC "Ural Steel", JSC "Cement Plant", JSC "Novotroitsk Silicate Materials Plant", JSC "Novotroitsk Chromium Compounds Plant", LLC "Novotroitsk Meat Processing Plant", Novotroitsk Branch of OJSC "Uralelektroremont Concern", JSC "Novotroitsk Bread Products Plant", LLC "Moloko"). In the city of Mednogorsk, the main origins of pollution are JSC "Mednogorsk Copper and Sulfur Plant", JSC "Mednogorsk Elektrotechnical Plant "Uralelektro", cogeneration plant of Mednogorsk and LLC "Mednogorsk Brick Plant".

In the rural settlements territory, the main origins of environmental pollution are road transport, heat power and food industry enterprises, and agricultural companies.

Mednogorsk is located on the territory of 0.4 thousand $\mathrm{km}^{2}$, the population for the period under study: 29.78 thousand people. Persons who have not reached working age make up $25 \%$ of the population, $60 \%$ are persons of working age and $15 \%$ - are over working age.

The area of Novotroitsk is 0.4 th. $\mathrm{km} 2$, the population is 100.94 thousand people. According to the review of the population structure, $21 \%$ are older than the working age, $64 \%$ are in the working age, and $15 \%$ of the population - are under the working age.

Ilekskiy district has an area of 3.6 th. $\mathrm{km} 2$, the average population: 23.89 thousand people. When studying the population structure, it was found that $23 \%$ were people under the working age, $52 \%$ were of the working age, $25 \%$ - older the working age.
Oktyabrskiy and Tyul'ganskiy districts occupy an area of 2.7 and 1.9 thousand $\mathrm{km} 2$, respectively. The population for the period under study made 22.59 and 23.46 thousand people, respectively.

Data analysis on carcinogens found in the atmospheric air of Mednogorsk showed that the highest individual carcinogenic risks are made by chromium compounds $(2.8 \times 10-3$, share in the total carcinogenic risk $35.3 \%$ ). The total life-long carcinogenic risk as a result of exposure to air pollutants is $3.31 \times 10-3$, which is considered as unacceptable (Table 1).

In Novotroitsk, the highest individual carcinogenic risk was established for chromium (4.31 x 10-3, 92.7\%). For Novotroitsk, the total carcinogenic risk from carcinogens contained in the atmospheric air makes $4.65 \times 10$ 3 , which is regarded as unacceptable carcinogenic risk (see Table 1).

The carcinogenic effect assessment for Oktyabrskiy district showed that the highest individual carcinogens risk in the atmospheric air was of chrome $(6.2 \times 10-4,46 \%)$ and arsenic $(6.1 \times 10-4,45 \%)$, which made $91 \%$ of the total carcinogenic risk equaling to $1.35 \times 10-3$ (Table 2).

In Ilekskiy district, the maximum share $(82 \%)$ to the total carcinogenic risk accounts for chromium (ICR $4.15 \times 10-3$ ). The total carcinogenic risk made $5.1 \times 10-3$, which is evaluated as the unacceptable carcinogenic risk.

The highest individual carcinogenic risk from substances in the atmospheric air in Oktyabrskiy district was established for arsenic $(1.3 \times 10-3,78.5 \%)$. The second rank was for benzene $(1.4 \times 10-4,9 \%)$. The total carcinogenic risk for Oktyabrskiy district made $1.6 \mathrm{x}$ 10-3.

Analysis of carcinogenic risk from exposure to chemicals contained in drinking water showed that the maximum individual carcinogenic risk for the city of Mednogorsk was established for arsenic $(3.8 \times 10-4,59.1 \%)$ and chromium $(2.2 \% 10-4,33.5 \%)$. The total carcinogenic risk from chemicals contained in drinking water for Mednogorsk made $6.44 \mathrm{x}$ 10-4 (Table 3). 
Table 1

Life-long carcinogenic risk from exposure to chemicals in ambient air

\begin{tabular}{|l|c|c|c|c|}
\hline \multirow{2}{*}{\multicolumn{1}{|c|}{ Chemical Substance }} & \multicolumn{2}{c|}{ Mednogorsk city } & \multicolumn{2}{c|}{ Novoroitsk city } \\
\cline { 2 - 5 } & \multicolumn{1}{|c|}{$I C R$} & Share, $\%$ & $I C R$ & Share, $\%$ \\
\hline Formaldehyde & $1,15 \mathrm{E}-04$ & 14,5 & $1,35 \mathrm{E}-04$ & 2,90 \\
\hline Benz (a) pyrene & $3,65 \mathrm{E}-07$ & 0,0 & $1,58 \mathrm{E}-07$ & 0,00 \\
\hline Benzene & $1,14 \mathrm{E}-04$ & 14,4 & $1,26 \mathrm{E}-05$ & 0,27 \\
\hline Ethylbenzene & $4,59 \mathrm{E}-06$ & 0,6 & $3,85 \mathrm{E}-06$ & 0,08 \\
\hline Styrene & $1,55 \mathrm{E}-06$ & 0,2 & $2,68 \mathrm{E}-06$ & 0,06 \\
\hline Chromium & $2,8 \mathrm{E}-03$ & 35,3 & $4,31 \mathrm{E}-03$ & 92,71 \\
\hline Lead & $9,56 \mathrm{E}-07$ & 0,1 & 0 & 0,00 \\
\hline Arsenic & $1,04 \mathrm{E}-04$ & 13,3 & 0 & 0,00 \\
\hline Soot & $7,38 \mathrm{E}-05$ & 9,3 & $1,74 \mathrm{E}-04$ & 3,74 \\
\hline Nickel & $1,34 \mathrm{E}-05$ & 1,7 & 0 & 0,00 \\
\hline Cobalt & $5,22 \mathrm{E}-05$ & 6,6 & 0 & 0,00 \\
\hline Cadmium & $2,00 \mathrm{E}-05$ & 2,5 & 0 & 0,00 \\
\hline Chloroform & $3,10 \mathrm{E}-06$ & 0,4 & $8,00 \mathrm{E}-08$ & 0,00 \\
\hline Carbon tetrachloride & $8,44 \mathrm{E}-06$ & 1,1 & $1,03 \mathrm{E}-05$ & 0,22 \\
\hline Total risk & $\mathbf{3 , 3 1 E - 0 3}$ & & $\mathbf{4 , 6 5 E}-03$ & \\
\hline
\end{tabular}

Table 2

Life-long carcinogenic risk from exposure to chemicals in ambient air

\begin{tabular}{|c|c|c|c|c|c|c|}
\hline \multirow{2}{*}{ Chemical Substance } & \multicolumn{2}{|c|}{ Tyul'gansky district } & \multicolumn{2}{|c|}{ Ilekskiy district } & \multicolumn{2}{|c|}{ Oktyabrskiy district } \\
\hline & $I C R$ & Share, \% & $I C R$ & Share, $\%$ & $I C R$ & Share, $\%$ \\
\hline Formaldehyde & $3,55 \mathrm{E}-05$ & 2,63 & $9,05 \mathrm{E}-05$ & 1,78 & $3,26 \mathrm{E}-05$ & 2,04 \\
\hline Benz (a) pyrene & $1 \mathrm{E}-07$ & 0,01 & $4,46 \mathrm{E}-07$ & 0,01 & $8,25 \mathrm{E}-08$ & 0,01 \\
\hline Benzene & $3,46 \mathrm{E}-06$ & 0,26 & 7,12E-04 & 14,04 & 0,00014 & 8,74 \\
\hline Ethylbenzene & $3,34 \mathrm{E}-07$ & 0,02 & 0 & 0,00 & $2,24 \mathrm{E}-06$ & 0,14 \\
\hline Styrene & $3,96 \mathrm{E}-07$ & 0,03 & 0 & 0,00 & $3,89 \mathrm{E}-07$ & 0,02 \\
\hline Chromium & $6,2 \mathrm{E}-04$ & 45,94 & $4,146 \mathrm{E}-03$ & 81,7 & $1,87 \mathrm{E}-05$ & 1,17 \\
\hline Lead & $1,72 \mathrm{E}-07$ & 0,01 & $1,89 \mathrm{E}-06$ & 0,04 & $1,89 \mathrm{E}-06$ & 0,12 \\
\hline Arsenic & $6,13 \mathrm{E}-04$ & 45,39 & 0 & 0,00 & $1,3 \mathrm{E}-03$ & 78,46 \\
\hline Soot & $1,95 \mathrm{E}-05$ & 1,45 & 0 & 0,00 & $2,91 \mathrm{E}-05$ & 1,82 \\
\hline Nickel & $4,07 \mathrm{E}-05$ & 3,02 & $2,84 \mathrm{E}-06$ & 0,06 & $2,43 \mathrm{E}-06$ & 0,15 \\
\hline Cobalt & $4,87 \mathrm{E}-06$ & 0,36 & $2,67 \mathrm{E}-05$ & 0,53 & $8,88 \mathrm{E}-05$ & 5,55 \\
\hline Cadmium & $2,66 \mathrm{E}-06$ & 0,20 & $9,23 \mathrm{E}-05$ & 1,8 & 0,000012 & 0,75 \\
\hline Chloroform & $5,67 \mathrm{E}-06$ & 0,42 & 0 & 0,00 & $2,12 \mathrm{E}-06$ & 0,13 \\
\hline Carbon tetrachloride & $3,61 \mathrm{E}-06$ & 0,27 & 0 & 0,00 & $1,44 \mathrm{E}-05$ & 0,90 \\
\hline Total risk & 1,35E-03 & & $5,1 \mathrm{E}-03$ & & $1,6 \mathrm{E}-03$ & \\
\hline
\end{tabular}

Table 3

Carcinogenic risk from exposure to chemicals in drinking water

\begin{tabular}{|l|c|c|c|c|}
\hline \multirow{2}{*}{\multicolumn{1}{c|}{ Chemical Substance }} & \multicolumn{2}{c|}{ Mednogorsk city } & \multicolumn{2}{c|}{ Novoroitsk city } \\
\cline { 2 - 5 } & $I C R$ & Share, $\%$ & $I C R$ & Share, $\%$ \\
\hline Arsenic & $3,8 \mathrm{E}-04$ & 59,1 & $2,14 \mathrm{E}-04$ & 61,85 \\
\hline Lead & $4,32 \mathrm{E}-06$ & 0,67 & $2,39 \mathrm{E}-06$ & 0,69 \\
\hline Chromium & $2,16 \mathrm{E}-04$ & 33,5 & $1,2 \mathrm{E}-04$ & 34,6 \\
\hline Beryllium & 0 & 0,00 & 0 & 0,00 \\
\hline Cadmium & 0 & 0,00 & 0 & 0,00 \\
\hline $2.4 \mathrm{D}$ & $8,686 \mathrm{E}-07$ & 0,13 & 0 & 0,00 \\
\hline Benz (a) pyrene & $9,91 \mathrm{E}-06$ & 1,54 & 0 & 0,00 \\
\hline Benzol & $8,486 \mathrm{E}-06$ & 1,32 & 0 & 0,00 \\
\hline Chloroform & $2,242 \mathrm{E}-07$ & 0,03 & $2,28 \mathrm{E}-06$ & 0,66 \\
\hline
\end{tabular}


End of Table 3

\begin{tabular}{|l|c|c|c|c|}
\hline \multirow{2}{*}{ Chemical Substance } & \multicolumn{2}{c|}{ Mednogorsk city } & \multicolumn{2}{c|}{ Novoroitsk city } \\
\cline { 2 - 5 } & $I C R$ & Share, $\%$ & $I C R$ & Share, $\%$ \\
\hline Carbon tetrachloride & $1,931 \mathrm{E}-06$ & 0,30 & $3,87 \mathrm{E}-06$ & 1,12 \\
\hline 1,2-Dichloroethane & $1,04 \mathrm{E}-05$ & 1,62 & 0 & 0,00 \\
\hline Tetrachlorethylene & $9,509 \mathrm{E}-07$ & 0,15 & 0 & 0,00 \\
\hline Bromodichloromethane & $2,645 \mathrm{E}-06$ & 0,41 & $2,42 \mathrm{E}-06$ & 0,70 \\
\hline Dibromochloromethane & $6,56 \mathrm{E}-06$ & 1,02 & $1,09 \mathrm{E}-06$ & 0,31 \\
\hline Bromoform & $2,483 \mathrm{E}-07$ & 0,04 & $1,08 \mathrm{E}-07$ & 0,03 \\
\hline Ethinyl trichloride & $4,086 \mathrm{E}-07$ & 0,06 & $7,14 \mathrm{E}-09$ & 0,00 \\
\hline DDT & $9,714 \mathrm{E}-07$ & 0,15 & 0 & 0,00 \\
\hline Total risk & $\mathbf{6 , 4 4 E - 0 4}$ & & $\mathbf{3 , 4 6 E - 0 4}$ & \\
\hline
\end{tabular}

Table 4

Carcinogenic risk from exposure to chemicals in drinking water

\begin{tabular}{|l|c|c|c|c|c|c|}
\hline \multirow{2}{*}{ Chemical Substance } & \multicolumn{2}{|c|}{ Ilekskiy district } & \multicolumn{2}{c|}{ Oktyabrskiy district } & \multicolumn{2}{c|}{ Tyul'gansky district } \\
\cline { 2 - 7 } & $I C R$ & Share, $\%$ & $I C R$ & Share, $\%$ & $I C R$ & Share, $\%$ \\
\hline Arsenic & $2,11 \mathrm{E}-04$ & 35,4 & $8,16 \mathrm{E}-05$ & 36,6 & $1,34 \mathrm{E}-04$ & 72 \\
\hline Lead & $4,05 \mathrm{E}-07$ & 0,07 & 0 & 0 & $2,84 \mathrm{E}-06$ & 1,5 \\
\hline Chromium & $1,58 \mathrm{E}-04$ & 26,5 & $4,8 \mathrm{E}-05$ & 21,5 & $1,91 \mathrm{E}-05$ & 10,3 \\
\hline Beryllium & $2,46 \mathrm{E}-05$ & 4,1 & $3,93 \mathrm{E}-06$ & 1,76 & $8,49 \mathrm{E}-06$ & 4,56 \\
\hline Cadmium & $9,46 \mathrm{E}-06$ & 1,6 & $2,93 \mathrm{E}-05$ & 13,2 & $9,05 \mathrm{E}-07$ & 0,49 \\
\hline 2.4 D & $1,04 \mathrm{E}-06$ & 0,18 & $1,65 \mathrm{E}-07$ & 0,07 & 0 & 0 \\
\hline Benz (a) pyrene & $1,74 \mathrm{E}-04$ & 29,2 & $4,92 \mathrm{E}-05$ & 22,1 & $1,49 \mathrm{E}-05$ & 8 \\
\hline Benzol & 0 & 0 & $4,62 \mathrm{E}-07$ & 0,21 & 0 & 0 \\
\hline Chloroform & $9,3 \mathrm{E}-08$ & 0,016 & $7,94 \mathrm{E}-08$ & 0,036 & $3,49 \mathrm{E}-08$ & 0,019 \\
\hline Carbon tetrachloride & $1,98 \mathrm{E}-06$ & 0,33 & $1 \mathrm{E}-06$ & 0,45 & $2,79 \mathrm{E}-07$ & 0,15 \\
\hline 1,2-Dichloroethane & $1,16 \mathrm{E}-05$ & 1,9 & $5,85 \mathrm{E}-06$ & 2,6 & $1,63 \mathrm{E}-06$ & 0,87 \\
\hline Tetrachlorethylene & 0 & 0 & $5,46 \mathrm{E}-07$ & 0,25 & $3,4 \mathrm{E}-06$ & 1,8 \\
\hline Bromodichloromethane & $1,26 \mathrm{E}-06$ & 0,21 & $6,38 \mathrm{E}-07$ & 0,29 & $1,77 \mathrm{E}-07$ & 0,095 \\
\hline Dibromochloromethane & $2,13 \mathrm{E}-06$ & 0,36 & $1,08 \mathrm{E}-06$ & 0,48 & $3 \mathrm{E}-07$ & 0,16 \\
\hline Bromoform & $2,01 \mathrm{E}-07$ & 0,034 & $1,02 \mathrm{E}-07$ & 0,046 & $2,82 \mathrm{E}-08$ & 0,015 \\
\hline Ethinyl trichloride & $4,19 \mathrm{E}-07$ & 0,07 & $2,04 \mathrm{E}-07$ & 0,09 & 0 & 0 \\
\hline DDT & 0 & 0 & $6,94 \mathrm{E}-07$ & 0,31 & 0 & 0 \\
\hline Total risk & $\mathbf{5 , 9 5 E - 0 4}$ & & $\mathbf{2 , 2 3 E - 0 4}$ & & $\mathbf{1 , 8 6 E}-04$ & \\
\hline
\end{tabular}

When assessing the carcinogenic risk in Novoroitsk, it was found that the highest individual carcinogenic risk was in arsenic $(2.14 \mathrm{x}$ $10-4,61.9 \%)$ and chromium (1.2 x 10-4, $34.6 \%)$.

The total carcinogenic risk in Novotroitsk made $3.46 \times 10-4$, which is regarded as the unacceptable carcinogenic risk to population (Table 3).

The assessment of carcinogenic risk in the Ilekskiy district territory showed that the highest individual carcinogenic risk was established for arsenic $\left(2.11 \times 10^{-4}, 35.4 \%\right)$, benz (a) pyrene $\left(1.74 \times 10^{-4}, 29.2 \%\right)$; chromium $\left(1.58 \times 10^{-4}, 26.5 \%\right)$. The total carcinogenic risk makes $5.95 \times 10^{-4}$ (Table 4 ).
In the analysis of carcinogenic risk in Oktyabrskiy district, the highest individual carcinogenic risk was found in arsenic $\left(8.16 \times 10^{-}\right.$ $5,36.6 \%)$, benz (a) pyrene $\left(4.92 \times 10^{-5}, 22.1 \%\right)$ and chromium $\left(4.8 \times 10^{-5}, 21.5 \%\right)$. The total carcinogenic risk equals to $2.23 \times 10^{-4}$ (see Table 4).

In Tyul'gansky district, the highest individual risk was established for arsenic $(1.34 \mathrm{x}$ $\left.10^{-4}, 72.0 \%\right)$ and chromium (1.91 $\times 10^{-5}$, $10.3 \%)$. The total carcinogenic risk makes $1.86 \times 10^{-4}$ (see Table 4).

In the analysis of the population risk, the highest population carcinogenic risk from exposure to air pollutants and drinking water was detected in Novotroitsk. The lowest population 
risk from carcinogens in atmospheric air was typical for Tyul'ganskiy district; from pollutants in drinking water - for Oktyabrskiy district (Table 5).

Table 5

Population carcinogenic risk

\begin{tabular}{|c|c|c|c|c|c|}
\hline $\begin{array}{r}\mathrm{Pa} \\
\text { rameter }\end{array}$ & $\begin{array}{r}\text { Ty } \\
\text { ul' gansk } \\
\text { y district }\end{array}$ & $\begin{array}{l}\text { Ile } \\
\text { kskiy } \\
\text { district }\end{array}$ & $\begin{array}{l}\text { Ok- } \\
\text { tyabrskiy } \\
\text { district }\end{array}$ & $\begin{array}{c}\mathrm{M} \\
\text { ed- } \\
\text { nogorsk } \\
\text { city }\end{array}$ & $\begin{array}{r}\text { No } \\
\text { voroitsk } \\
\text { city }\end{array}$ \\
\hline$\overline{\mathrm{Ai}}$ & $7^{31,}$ &,$^{121}$ & $1^{36,}$ & $6^{98,}$ & $\begin{array}{r}46 \\
9,4\end{array}$ \\
\hline ater $\mathrm{W}$ & $0^{14,}$ & 5,3 & 4,2 & $2^{19,}$ & $9^{34,}$ \\
\hline
\end{tabular}

The basic origin for uncertainties is related to incomplete information about all the polluting chemical carcinogens. When assessing the exposure, uncertainty is associated with the specifics of environmental monitoring, since such control takes place only over the priority pollutants identified for the entire territory of Orenburg region.

In determining carcinogenic risk of atmospheric air, the uncertainty is due to the fact that to assess risks we use concentrations obtained from the values of the maximum onetime concentrations, which is especially typical for sampling route sites. This affects overestimation of the total risk value.

It should be noted that when detecting arsenic in drinking water, sensitivity of the applied technique is higher than the reference level, which can lead to reassessment of individual risk, nevertheless, in the comparative analysis of territories under study, using the results is allowable.

Uncertainty in the present work is also related to conventionality of the selected exposure scenario, which does not fully take into account the specific aspects in daily activity of the popula- tion belonging to different age and sex groups, in particular, the time that the potentially exposed population stays in the territory under study.

Therefore, the obtained values of risk parameters in this paper can be considered as relative. The most accurate results in assessing the effect of environmental hazards to health can be really established only in the properly scheduled and targeted epidemiological studies, reducing the uncertainty levels (if possible) by using analytical and laboratory data, and developing scenarios that are closest to real situations.

Conclusions. Thus, as a result of risk assessment in monocities and rural settlements, it was found that the total carcinogenic risk from exposure to chemicals in the air is considered as unacceptable. Such risk requires urgent curative measures.

Carcinogenic risk of chemicals contained in drinking water, both in monocities, and rural settlements, is considered as acceptable, but for monocities it is 1.5-2.0 times higher.

Chromium took the leading role among carcinogens in the atmospheric air of monocities, for rural settlements these were arsenic and benzene.

Among carcinogens contained in drinking water, for rural settlements, chrome and benz (a) pyrene took the leading place, for monocities - arsenic.

The present research is practically important for optimizing and improving the SHM (sanitary and hygienic monitoring) system at the regional level in order to improve data collection system. It is necessary to work out regional programs and activities in assessment of economic damage to public health due to environment pollution.

\section{References}

1. Byctpykh V.V. Gigienicheskaya otsenka vliyaniya pit'evoi vody na zdorov'e [Hygienic assessment of influence exerted on health by drinking water]. Gigiena $i$ sanitariya, 1998, no. 6, pp. 20-22 (in Russian).

2. Bystrykh V.V., Tin'kov A.N.. Makshantsev S.S., Salikhova L.R. Voprosy otsenki ekologicheskogo riska dlya naseleniya [Issues of assessing ecological risk for population]. Zashchitaokruzhayushcheisredy v neftegazovomkomplekse, 2004, no. 8, pp. 67 (in Russian).

3. Zaitseva N.V., May I.V. Regional'nyi opyt ucheta pokazatelei riska dlya zdorov'ya naseleniya v zadachakh prostranstvennogo planirovaniya [Regional experience in accounting parameters of population health risk in spatial planning tasks]. Ars Administrandi, 2011, no. 2, pp. 30-39 (in Russian). 
4. Novikov S.M., Fokin M.V., Unguryanu T.N. Aktual'nye voprosy metodologii i razvitiya dokazatel'noi otsenki riska zdorov'yu naseleniya pri vozdeistvii khimicheskikh veshchestv [Actual problem of methodology and development of evidence-based health risk assessment associated with chemical exposure]. Gigiena i sanitariya, 2016, vol. 95, no 8, pp. 711-716 (in Russian).

5. O sostoyanii sanitarno-epidemiologicheskogo blagopoluchiya naseleniya v Orenburgskoi oblasti v 2015 godu: Gosudarstvennyi doklad [On sanitary-epidemiologic well-being of the population in Orenburg region in 2015: State report]. Orenburg, Upravlenie Federal'noi sluzhby po nadzoru v sfere zashchity prav potrebitelei i blagopoluchiya cheloveka po Orenburgskoi oblasti Publ., 2016, 263 p. (in Russian).

6. Obzor sostoyaniya i zagryazneniya okruzhayushchei sredy v Rossiiskoi Federatsii za 2012 god. [Review on the state and contamination of the environment in the Russian Federation over 2012]. Moscow, Federal'naya sluzhba po gidrometeorologii i monitoringu okruzhayushchei sredy Publ., 2013, 178 p. (in Russian).

7. Anan'ev V.Yu., Kaisarova N.A., Kiku P.F., Izmailova O.A., Trunova I.E. Otsenka riska vozdeistviya na naselenie khimicheskikh kontaminantov $\mathrm{v}$ pishchevykh produktakh i pit'evoi vode [Estimation of risk of influence on the population chemical substances in foodstuff and potable water]. Zdorov'e naseleniya i sreda obitaniya, 2011, no. 8, pp. 30-34 (in Russian).

8. Avaliani S.L., Bezpal'ko L.E., Bobkova A.L., Mishina A.L. Perspektivnye napravleniya razvitiya metodologii analiza riska $\mathrm{v}$ Rossii [The perspective directions of development of methodology of the analysis of risk in Russia]. Gigiena i sanitariya, 2013, no. 1, pp. 33-35 (in Russian).

9. Avaliani S.L., Novikov S.M., Shashina T.A., Dodina N.S., Kislitsin V.A., Mishina A.L. Problemy sovershenstvovaniya sistemy upravleniya kachestvom okruzhayushchei sredy na osnove analiza riska zdorov'yu naseleniya [The urgent problems of the improvement of the environment management system based on the analysis of health risk assessment]. Gigiena i sanitariya, 2014, vol. 93, no. 6, pp. 5-8 (in Russian).

10. Rukovodstvo po ocenke riska dlja zdorov'ja naselenija pri vozdejstvii himicheskih veshhestv, zagrjaznjajushhih okruzhajushhuju sredu R 2.1.10.1920-04 [Guide to health risk assessment when exposed to chemicals polluting the environment 2.1.10.1920-04]. Moscow, Federal'nyj centr Gossanjepidnadzora Minzdrava Rossii publ., 2004, 143 p. (in Russian).

11. Setko A.G., Ochneva G.I., Setko I.M. Faktory, formiruyushchie zdorov'e detskogo naseleniya, prozhivayushchego na urbanizirovannykh territoriyakh, i otsenka riska ikh vozdeistviya [Factors which form health of children population living in urbanized territories and assessment of risks caused by their impacts]. Vestnik Orenburgskogo gosudarstvennogo universiteta, 2005, no. S5, pp. 104-106.

12. Surzhikov V.D., Surzhikov D.V. Otsenka i upravlenie riskom dlya zdorov'ya ot mnogokomponentnogo zagryazneniya okruzhayushchei sredy krupnogo tsentra metallurgii [Assessment and management of human risk due multicomponent environmental pollution in a large metallurgy center]. Gigiena $i$ sanitariya, 2006, no. 5, pp. 32-35 (in Russian).

13. Frolova O.A., Karpova M.V. Otsenka riska razvitiya kantserogennykh i nekantserogennykh effektov pri upotreblenii produktov pitaniya [Risk assessment of carcinogenic and non-carcinogenic effects in the use of food]. Gigiena $i$ sanitariya, 2012, no. 5, pp. 107-108 (in Russian).

14. Environment and health in the WHO European Region: progress, challenges and lessons learned: working document: Regional Committee for Europe 65th session. World Health Organization, Vilnius, 2015, $15 \mathrm{p}$.

15. Progress report on the European Environment and Health Process: working document: Regional Committee for Europe 66th session. World Health Organization, Copenhagen, 2016, 16 p.

Boev V.M., Kryazhev D.A., Tulina L.M., Neplokhov A.A. Assessment of carcinogenic health risk for population living in monocities and rural settelements. Health Risk Analysis, 2017, no. 2, pp. 5460. DOI: 10.21668/health.risk/2017.2.06.eng

Received: 14.01.2017

Accepted: 06.03.2017

Published: 30.06 .2017 